DZIAŁ TEMATYCZNY:

Czasopisma i (czaso)piśmiennictwo pedagogiczne

\begin{tabular}{|c|c|}
\hline & $\begin{array}{c}\text { Forum Pedagogiczne } \\
11(2021) 1\end{array}$ \\
\hline SŁAWOMIR PASIKOWSKI* & $\begin{array}{r}\text { Wpłynęło: } 22 \text { marca } 2021 \\
\text { Zatwierdzono do druku: } 6 \text { kwietnia } 2021 \\
\text { DOI: } 10.21697 / \text { fp.2021.1.02 }\end{array}$ \\
\hline Łódź, Polska & \\
\hline ORCID ID: 000o-0002-0768-1596 & \\
\hline
\end{tabular}

\title{
AFILIACJA CZASOPISM DO PEDAGOGIKI, PSYCHOLOGII I NAUK SOCJOLOGICZNYCH W ŚWIETLE DANYCH \\ Z WYKAZU CZASOPISM PUNKTOWANYCH PRZEZ MINISTERSTWO NAUKI I SZKOLNICTWA WYŻSZEGO W ROKU 2019
}

\begin{abstract}
Streszczenie: Jednym z podstawowych instrumentów ewaluacji nauki są rankingi czasopism, które określają wartość publikacji afiliowanych do poszczególnych dyscyplin naukowych. Zmiana warunków ewaluacji, wprowadzona w Polsce reformą Konstytucja dla nauki, wyznacza nowe zasady oceny czasopism i publikowanych w nich prac. Pozwala przyjrzeć się bliżej relacjom między dyscyplinami naukowymi. Artykuł prezentuje wyniki badań, w których wykorzystano dane z pierwszej wersji ministerialnego wykazu czasopism punktowanych, opublikowanego w 2019 roku. Analizie poddano punktację i współafiliacje czasopism do pedagogiki i najbliżej współpracujących z nią dyscyplin, tj. psychologii i nauk socjologicznych. Rezultaty wskazują na podobieństwo rozkładów punktacji czasopism, różnice zaś widoczne są w strukturze afiliacji czasopism do dyscypliny i współdzielenia tej afiliacji.
\end{abstract}

Słowa kluczowe: punktacja czasopism, afiliacja czasopism, reforma nauki.

\section{Wprowadzenie}

Ocena jakości czasopism stanowi element mechanizmu ewaluacji parametrycznej dyscyplin oraz jednostek naukowych, i jest jednym z najważniejszych instrumentów tej ewaluacji (Kulczycki 2017a). Wśród miar oceny jakości czasopism do najpopularniejszych w Polsce należą: Impact Factor (IF), CiteScore (CS), Index Copernicus

\footnotetext{
* Dr hab. Sławomir Pasikowski, prof. uczelni, Uniwersytet Łódzki, Katedra Badań Edukacyjnych, Wydział Nauk o Wychowaniu; e-mail: slawomir.pasikowski@now.uni.lodz.pl.
} 
(IC) oraz Wykaz Czasopism Punktowanych (WCP). W szczególności ta ostatnia miara brana jest pod uwagę w krajowej instytucjonalnej ewaluacji dyscyplin oraz pracowników naukowych. Większość podobnych miar opiera się o dane z baz Scopus oraz Web of Science Core Collection. Niekiedy, jak w przypadku WCP, mierniki jakości czasopism uwzględniają też jakościowe oceny zespołów eksperckich. WCP ma ponad 2o-letnią tradycję. Ostatnia znacząca zmiana WCP nastąpiła w roku 2019 w ramach reformy nazwanej Konstytucja dla nauki, która realizowana była przez Ministerstwo Nauki i Szkolnictwa Wyższego (MNiSW). Reforma ta wprowadziła nową procedurę tworzenia ministerialnego rankingu czasopism na mocy Rozporządzenia Ministra Nauki i Szkolnictwa Wyższego z dnia 7 listopada 2018 roku w sprawie sporządzania wykazów wydawnictw monografi naukowych oraz czasopism naukowych i recenzowanych materiałów $z$ konferencji międzynarodowych. Założonym efektem instytucjonalizowania rankingów czasopism i wydawnictw jest wzrost produktywności pracowników nauki oraz poprawa jakości publikacji. Zarazem zwraca się jednak uwagę na niesione przez takie rankingi ryzyko pogoni za punktami (tzw. punktowy) i patologii, które ta pogoń generuje (Kulczycki 2017b), jak również patologii cytowań (Kokowski 2019). To cytowania są w istocie podstawą określania wskaźników wpływu czasopism, na których opierają się takie rankingi. Choć wyraźnie podkreślana jest również potrzeba wprowadzania nowych kryteriów, wolnych od wad wskaźników wpływu (por. Ginieis, Li 2020; Packalen, Bhattacharya 2017; Wijewickrema, Petras 2017; Zhang i in. 2019).

\section{Procedura oceny czasopism}

W Polsce instytucjonalna ocena publikacji oparta jest na tzw. zasadzie dziedziczenia prestiżu, zgodnie z którą wartość danej publikacji odpowiada wartości czasopisma albo wydawnictwa, w którym została ona wydana. W związku z tym w krajowym systemie ewaluacji obowiązuje wykaz czasopism naukowych i recenzowanych materiałów $\mathrm{z}$ konferencji międzynarodowych (WCP) oraz wykaz wydawnictw publikujących recenzowane monografie naukowe (WW). Pierwsza wersja WCP upubliczniona została przez MNiSW 31 lipca 2019 roku, następnie miała dwie aktualizacje: pierwszą - 2 sierpnia 2019 roku i drugą - 20 grudnia 2019 roku. Druga z aktualizacji obejmuje o 1367 tytułów więcej niż pierwsza wersja WCP z 31 lipca 2019 roku, co wskazuje na dynamikę prac mających na celu dostosowanie wykazu do oczekiwań, jakie są z nim wiązane.

Na mocy założeń i metodyki przyjętych w ramach Konstytucji dla nauki (Dańda i in. 2019) do opracowania WCP powołane zostały zespoły ekspertów, oddzielnie dla każdej z 44 dyscyplin naukowych, których zadanie polega na ocenie prestiżu periodyków oraz podstawy ich przypisania do wybranych dyscyplin naukowych. Prestiż czasopisma jest definiowany jako wpływ czasopisma na rozwój nauki i operacjonalizowany głównie jako liczba cytowań. Te z kolei obliczane są według takich wskaźników, jak: Source Normalized Impact per Paper (SNIP), CiteScore, 
Scimago Journal Rank (SJR), Journal Impact Factor (JIF), Article Influence Score (AI), Category Normalized Citation Impact (CNCI). Rozkład tak obliczonych cytowań opisywany jest za pomocą kwantyli, które podzielone na sześć przedziałów stanowią podstawę wyznaczania kategorii punktowych: do 25 centyla - 20 pkt., do 50 centyla - 40 pkt., do 75 centyla - 70 pkt, do 90 centyla - 100 pkt., do 97 centyla - 140 pkt., 97 centyl i wyższy - 200 pkt. Czasopisma, w przypadku których niemożliwe jest wyliczenie wskaźników cytowań, oceniane są według jakościowego kryterium: zakwalifikowanie periodyku do programu „Wsparcie dla czasopism naukowych", rekomendacja zespołu eksperckiego lub obecność na liście ERIH+. Takim czasopismom przypisywana jest kategoria 20 pkt. Ponadto zespoły eksperckie mogą też rekomendować zmianę kategorii punktowej dowolnego periodyku, o ile przedstawią uzasadnienie o stopniu prestiżu tego periodyku.

O ostatecznym kształcie WCP decyduje Komisja Ewaluacji Nauki, która zatwierdza albo odrzuca usytuowanie poszczególnych czasopism w zaproponowanym rankingu. Rozwiązaniem nowym w stosunku do wersji WCP sprzed reformy Konstytucja dla nauki jest afiliacja czasopism do dyscyplin naukowych. W myśl założeń leżących u podstaw wprowadzonych reform ma to usprawnić proces ewaluacji jakości działalności naukowej, m.in. przez ocenę tej jakości w zakresie dyscyplin, a nie jak poprzednio - jednostek naukowych (por. Dańda i in. 2019, s. 34). W ocenie tej brana jest pod uwagę liczba punktów przyznanych publikacji w roku jej wydania.

\section{Użytkowa wartość WCP}

Rankingi czasopism informują o sile oddziaływania poszczególnych periodyków na stan dyscypliny naukowej. Obserwacja periodyków ze szczytu rankingu pozwala zorientować się w zakresie tematyki oraz dominujących standardów metodycznych i komunikacyjnych $\mathrm{w}$ danej dyscyplinie. $Z$ kolei liczba czasopism afiliowanych do wybranej dyscypliny, jak też rozkład punktacji tych czasopism dostarczają informacji na temat zakresu możliwych wyborów oferowany reprezentantom tejże dyscypliny zainteresowanych publikowaniem wyników swojej pracy. Jednocześnie stwarzają one możliwość dokonywanie porównań i określania powiązań afiliacyjnych pomiędzy dyscyplinami, a tym samym nakreślania obrazu międzydyscyplinarnych inklinacji. Ponadto opis rozkładów punktacji czasopism można wykorzystać do oszacowania punktowego zysku leżącego w zasięgu nie tylko pojedynczego autora, lecz także wszystkich członków interdyscyplinarnych zespołów autorów. Taki szacunek może być interesujący, zwłaszcza gdy chce się ocenić, czy w zakresie możliwych punktacji i liczebności czasopism interesy poszczególnych dyscyplin są zrównoważone. 


\section{Związki pedagogiki z psychologią i socjologią w perspektywie WCP}

Psychologia i socjologia traktowane są, obok filozofii, jako podstawowe dyscypliny współpracujące z pedagogiką. Znajduje to uzasadnienie zarówno w podzielanym przedmiocie badań, podzielanych teoriach, jak i w historii rozwoju tych dyscyplin (Banaszak 2018; Nowak 2012, s. 31; Palka 1999, s. 34, 36; Śliwerski 2007, 2020). Ważne jest również instytucjonalne przyporządkowanie tych trzech dyscyplin tej samej dziedzinie nauki, tj. naukom społecznym oraz finansowanie badań w postępowaniach konkursowych takich agencji, jak Narodowe Centrum Nauki, w ramach tego samego panelu. Związki pomiędzy tymi dyscyplinami uwidoczniają się także na poziomie administrowania jednostkami naukowymi, w których nazwy wydziałów lub instytutów zawierają koniunkcję nazw dyscyplin, np. „Wydział Pedagogiki, Psychologii i Socjologii” lub „Wydział Nauk Społecznych”, obejmujące kierunki kształcenia odpowiadające tymże trzem dyscyplinom. W związku z powyższym, w celu określenia specyfiki warunków publikacji, zasadne jest łączne obejmowanie ich obserwacją.

Pytania nasuwające się w kontekście pierwszej wersji WCP, wprowadzonego reformą Konstytucja dla nauki, są następujące:

- Czy zachodził związek pomiędzy dyscypliną naukową a punktacją czasopism?

- $\quad$ W jaki sposób kształtowało się współdzielenie afiliacji czasopism przez dyscyplinę naukową?

- Jaka była struktura podobieństwa afiliacji czasopism do dyscyplin naukowych?

Odpowiedzi na te pytania poszukiwano, eksplorując dane zawarte w dokumencie upublicznionym przez MNiSW.

\section{Metoda}

\section{Materiał badawczy}

W badaniu wykorzystano dane zastane, które zawierał jeden z dwóch arkuszy kalkulacyjnych pliku .xlsx, będącego załącznikiem do Komunikatu Ministra Nauki i Szkolnictwa Wyższego z dnia 18 grudnia 2019 roku w sprawie wykazu czasopism naukowych i recenzowanych materiałów z konferencji międzynarodowych. Arkusz, o którym mowa, zawiera 30404 rekordy. W każdym z nich widnieje nazwa pojedynczego czasopisma, identyfikator oraz numery ISBN i ISSN, przyporządkowana czasopismu punktacja oraz afiliacje związane $\mathrm{z} 44$ dyscyplinami. Oznaczone są one w oryginalnym arkuszu kodem dziedziny naukowej, do której dana dyscyplina przynależy, na mocy obowiązującej klasyfikacji dziedzin i dyscyplin naukowych. Jednostkę obserwacji stanowiło więc pojedyncze czasopismo o przyporządkowanej kategorii punktowej oraz przyporządkowanych afiliacjach do dyscyplin 
naukowych. W analizie uwzględniono zbiór jednostek obserwacji z afiliacją do co najmniej jednej z trzech dyscyplin naukowych, tj. pedagogiki, psychologii, nauk socjologicznych. Zbiór ten liczy 4801 elementów.

\section{Procedura}

Obserwacją objęte zostały trzy zmienne: punktacja czasopisma, dyscyplina naukowa oraz afiliacja czasopisma do dyscypliny naukowej. Punktacja czasopism jest zmienną zoperacjonalizowaną na skali porządkowej i przyjmującą w przypadku każdego czasopisma jedną z sześciu kategorii: 200, 140, 100, 70, 40, 20 pkt. Z kolei afiliacja periodyków do dyscyplin jest zmienną binarną: $\mathrm{w}$ oryginalnym pliku wprowadzano ' $\mathrm{x}$ ', jeśli czasopismo jest afiliowane do danej dyscypliny. $\mathrm{Na}$ potrzeby analizy zastosowano $\mathrm{w}$ przypadku tej zmiennej kodowanie o - 1, gdzie „1" oznacza „afiliowane”, i odpowiada oryginalnemu kodowaniu „x”, a „o" oznacza „brak afiliowania”.

\section{Instrumenty analizy danych}

W związku z tym, że wartości przypisywane czasopismom w WCP nie są punktami, lecz rangą, to wszelkie kalkulacje dokonywane z udziałem tych wartości powinny być prowadzone tak samo, jak ma to miejsce w przypadku zmiennych mierzonych na porządkowej skali pomiaru. $\mathrm{W}$ analizie zastosowano więc nieparametryczny opis rozkładu w zbiorowości generalnej, wskaźnik struktury oraz miarę współzmienności cech jakościowych. Do rozpoznania struktury zbioru afiliacji czasopism do dyscyplin i grupowania dyscyplin pod tym względem wykorzystano hierarchiczną analizę skupień dla liczebności. Analizę prowadzono tak, aby możliwe było obserwowanie wyników dla pedagogiki w kontekście wyników dla dziedzin psychologii i nauk socjologicznych, czyli uchodzących za główne pomocnicze dyscypliny pedagogiki.

\section{Wyniki}

\section{Związek pomiędzy dyscypliną naukową a punktacją czasopism}

Pedagogika, psychologia oraz nauki socjologiczne różniły się pod względem rozkładów punktacji czasopism. Zwłaszcza rozkład punktacji czasopism afiliowanych do nauk socjologicznych wyróżnia się na tle pozostałych (tabela pierwsza). Jednakże rozkłady udziałów względnych uwidoczniają podobieństwa pomiędzy dyscyplinami, które polegają na zależności: im niższa jest kategoria punktowa czasopisma, tym większa jest liczba czasopism tej kategorii afiliowanych do każdej z trzech dyscyplin (wykres pierwszy). 
Tabela 1. Rozkład punktacji czasopism w dyscyplinie (częstości, udziały względne)

\begin{tabular}{|l|c|c|c|}
\hline \multirow{2}{*}{ Punktacja } & \multicolumn{3}{|c|}{ Dyscyplina } \\
\cline { 2 - 4 } & Pedagogika & Psychologia & N. socjologiczne \\
\hline 200 & $46[0,028]^{*}$ & $32[0,026]$ & $80[0,024]$ \\
\hline 140 & $104[0,064]$ & $111[0,089]$ & $222[0,067]$ \\
\hline 100 & $208[0,129]$ & $197[0,157]$ & $440[0,133]$ \\
\hline 70 & $297[0,184]$ & $260[0,208]$ & $707[0,214]$ \\
\hline 40 & $293[0,181]$ & $223[0,178]$ & $635[0,192]$ \\
\hline 20 & $667[0,413]$ & $430[0,343]$ & $1215[0,368]$ \\
\hline Suma & $1615[1]$ & $1253[1]$ & $3299[1]$ \\
\hline
\end{tabular}

* W nawiasie kwadratowym podano wartość udziałów względnych (wskaźników struktury).

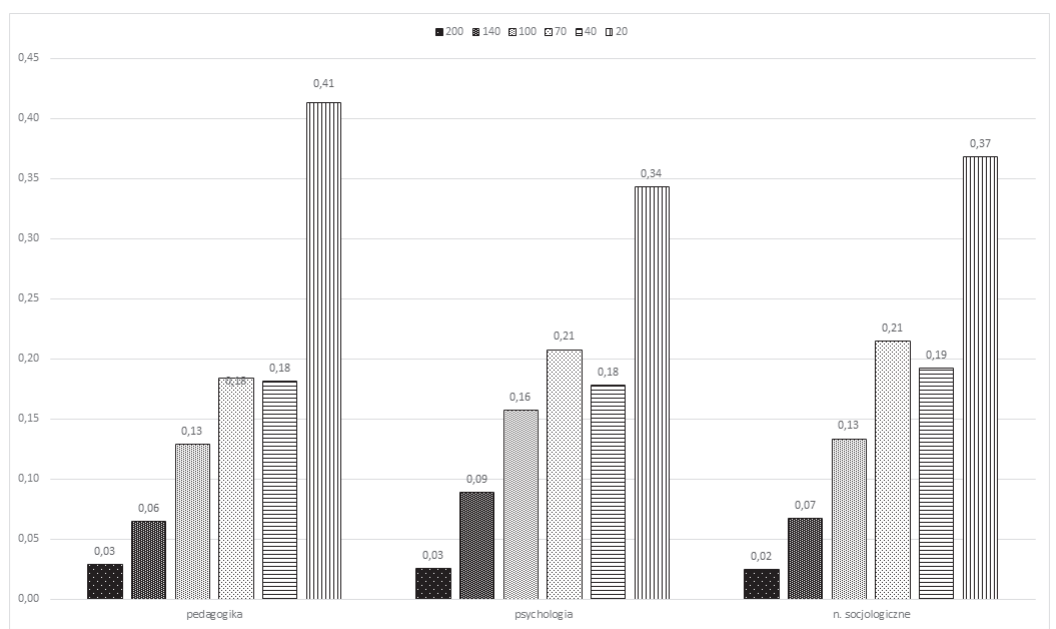

Wykres 1. Rozkłady punktacji czasopism w dyscyplinie (udziały względne)

Sformułowane powyżej spostrzeżenia znajdują potwierdzenie w wynikach analizy współzależności punktacji czasopism i dyscypliny naukowej (trzy warianty: pedagogika, psychologia, nauki socjologiczne). Współczynnik kontyngencji C, liczony z wartości współczynnika niezależności chi ${ }^{2}$ Pearsona, przyjmuje wartość poniżej o,1 $\left(\mathrm{chi}^{2}=29,00, \mathrm{df}=10, \mathrm{C}=0,07, \mathrm{C}_{\text {skor }}=0,08\right)$. Oznacza to, że związek między zmiennymi jest bardzo mały i praktycznie nieznaczący.

W związku z powyższym warto też zwrócić uwagę na związek dyscypliny $\mathrm{z}$ afiliacją czasopism prezentowaną w kolejnych wersjach WCP (tabela druga). Otóż w rozkładzie afiliacji dane dla pedagogiki wyróżniają się na tle psychologii i nauk socjologicznych, tj. przyrost czasopism przypisanych do pedagogiki jest niemal dwa razy większy niż w przypadku pozostałych dwóch dyscyplin. Jednakże ocena tego związku wykazała brak współzależności dyscypliny i afiliacji czasopism 
zaprezentowanych w kolejnych wersjach $\mathrm{WCP}\left(\mathrm{chi}^{2}=2,44, \mathrm{df}=2, \mathrm{C}=0,01, \mathrm{C}_{\text {skor }}\right.$ $=0,02)$.

Tabela 2. Liczba afiliacji czasopism do dyscypliny według kolejnych wersji WCP

\begin{tabular}{|l|c|c|c|c|}
\hline \multirow{2}{*}{ Dyscyplina } & WCP z 20.07.2019 & WCP z 20.12.2019 & \multicolumn{2}{|c|}{ Różnica } \\
\cline { 2 - 5 } & $\mathrm{n}$ & $\mathrm{n}$ & $\mathrm{n}$ & $\%$ \\
\hline Pedagogika & 1368 & 1615 & 247 & 18,06 \\
\hline Psychologia & 1132 & 1253 & 121 & 10,69 \\
\hline N. socjologiczne & 2989 & 3299 & 310 & 10,37 \\
\hline
\end{tabular}

\section{Współdzielona afiliacja czasopism do dyscypliny}

Współdzielona afiliacja rozumiana jest jako liczba afiliacji czasopisma do danej dyscypliny i do każdej z pozostałych dwóch dyscyplin. W tym zakresie występowały interesujące różnice pomiędzy pedagogiką, psychologią oraz naukami socjologicznymi. Wyniki ukazują występowanie tendencji do kojarzenia pedagogiki najpierw z naukami socjologicznymi, a następnie z psychologią. $Z$ kolei socjologia współafiliowała z psychologią mniej czasopism niż z pedagogiką. Powyższe wyniki nie oznaczają jednak, że nauki socjologiczne i pedagogikę cechowało większe podobieństwo struktury afiliacji w porównaniu do psychologii.

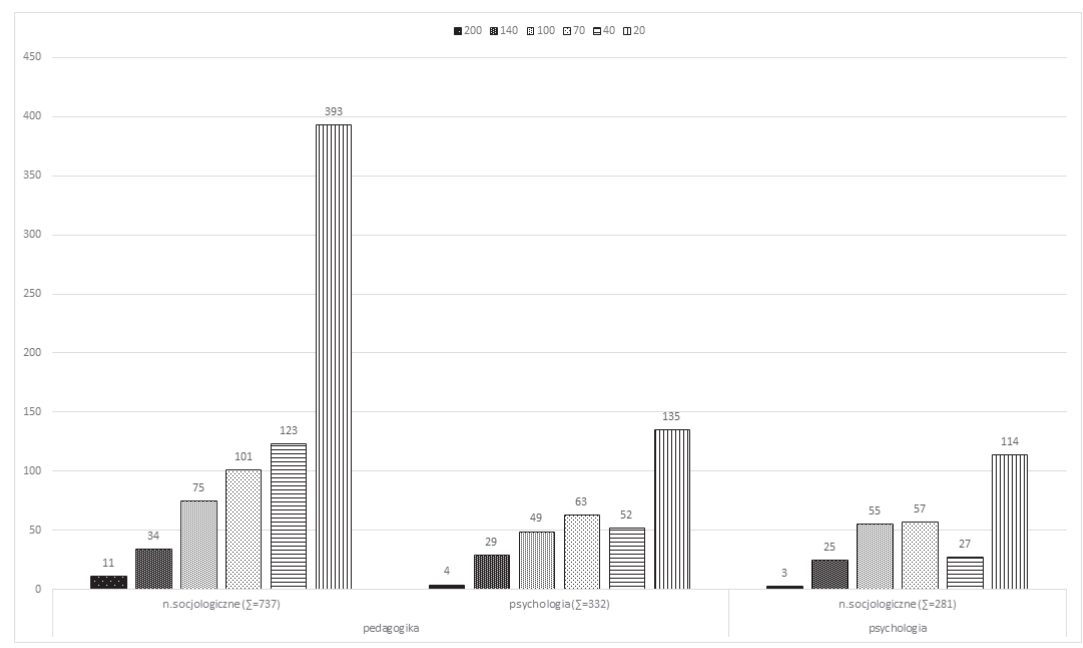

Wykres 2. Rozkłady afiliacji współdzielonej (częstości) 
Obserwacja stosunku sumy współafiliowanych czasopism do sumy afiliowanych czasopism pozwala określić, jaką część afiliacji stanowiła współafiliacja z wybraną dyscypliną. Otóż, blisko 46 procent (proc.) czasopism afiliowanych do pedagogiki było zarazem afiliowanych do nauk socjologicznych, z kolei 21 proc. zarazem do psychologii. W przypadku czasopism afiliowanych do psychologii 26 proc. było zarazem afiliowanych do pedagogiki, a 22 proc. - do nauk socjologicznych. Natomiast 22 proc. czasopism afiliowanych do nauk socjologicznych było zarazem afiliowanych do pedagogiki, a 8 proc. jednocześnie do psychologii.

\section{Struktura podobieństwa afiliacji czasopism do dyscypliny naukowej}

Struktura afiliacji czasopism w obrębie grupy tworzonej wspólnie przez trzy dyscypliny (pedagogika, psychologia, nauki socjologiczne) przeanalizowana została za pomocą hierarchicznej analizy skupień dla liczebności. Za miarę niepodobieństwa obiektów w zbiorze przyjęto kwadrat odległości euklidesowej, a odległość między skupieniami obliczono według metody środka ciężkości skupień. Na wykresie trzecim uwidoczniono dwa ogólniejsze skupienia: pierwsze - afiliacje do psychologii i do nauk socjologicznych, drugie - afiliacje do pedagogiki. Współczynniki odległości między skupieniami przedstawione są w tabeli trzeciej i wskazują, że generalnie stopień niepodobieństwa afiliacji do dyscypliny był podobny dla nauk socjologicznych, psychologii i pedagogiki, choć w przypadku pedagogiki podobieństwo do dwóch pozostałych dyscyplin było najmniejsze.

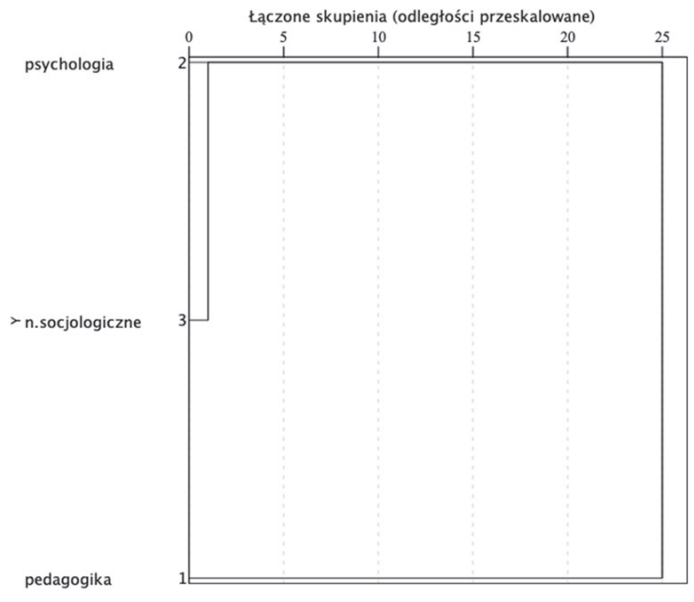

Wykres 3. Skupienia dyscyplin na podstawie afiliacji czasopism 
Tabela 3. Macierz współczynników odległości (wartości chi²)

\begin{tabular}{|l|c|c|c|}
\hline \multicolumn{1}{|c|}{ Dyscyplina } & Pedagogika & Psychologia & N. socjologiczne \\
\hline Pedagogika & & & \\
\hline Psychologia & 4,56 & & \\
\hline N. socjologiczne & 3,51 & 3,49 & \\
\hline
\end{tabular}

Struktura afiliacji czasopism do dyscypliny pedagogika kształtowała się więc nieco inaczej niż w przypadku psychologii i nauk socjologicznych, które pod tym względem były do siebie bardziej zbliżone. Ten subtelny efekt odzwierciedla się również w wartościach udziałów względnych (patrz: wykres pierwszy).

\section{Dyskusja}

Afiliacja czasopism punktowanych do dyscyplin stanowi jeden z kluczowych instrumentów ewaluacji nauki. Zarazem dane z instytucjonalnych rankingów czasopism dostarczają informacji o sankcjonowanym instytucjonalnie obrazie struktury nauki oraz o reputacji poszczególnych periodyków. Oddziałują przez to na popularność określonych zagadnień, jak też standardów metodycznych i standardów w zakresie komunikacji naukowej. Co więcej, pozwalają śledzić pogranicza dyscyplin, instytucjonalnie wzmacniane obszary współpracy i ograniczenia w tym zakresie. Również interesujące możliwości stwarzają takie rankingi w prowadzeniu obserwacji nad ewentualnymi faworyzacjami dyscyplin, popytem na wypowiedzi ich reprezentantów i podażą warunków wyznaczających stopień subwencjonowania naukowych aktywności, czy też zagrożenia wynikające z liczby czasopism i rozkładu współczynników ich wpływu (por. Casadevall, Fang 2012). W związku z powyższym zrozumiałe jest, że budzą powszechne zainteresowanie środowisk akademickich.

Zaprezentowane wyniki badań (nad afiliacją czasopism punktowanych do pedagogiki i najbliżej współpracujących z nią dyscyplin) dostarczają nieoczywistych rezultatów. Pod względem sumy afiliowanych czasopism dyscypliny różniły się między sobą, co wyrażało się m.in. tym, że pedagogika afiliowała blisko 400 periodyków więcej niż psychologia, a razem z psychologią afiliowały mniej czasopism niż nauki socjologiczne. Jednakże pomiędzy dyscypliną nauki oraz ministerialną punktacją czasopism nie zachodził związek o charakterze współwystępowania. Innymi słowy, proporcje udziału poszczególnych kategorii czasopism, wyróżnionych ze względu na punktację, były podobne w każdej z tych dyscyplin.

Pedagogika współdzieliła blisko połowę sumy afiliowanych do niej czasopism z naukami socjologicznymi, podczas gdy z psychologią już tylko jedną piątą tej sumy. W przypadku psychologii była to podobna wartość - około jedna czwarta sumy afiliowanych czasopism, współdzielonych z pedagogiką i naukami socjologicznymi. Nauki socjologiczne współdzieliły z pedagogiką około jedną czwartą sumy afiliowanych czasopism i niecałą jedną dziesiątą z psychologią. Wyraźny 
dryf pedagogiki w stronę nauk socjologicznych, w powiązaniu z pozostałymi wynikami, mógłby sugerować większe podobieństwo pedagogiki i nauk socjologicznych pod względem afiliacji czasopism, co być może jest skutkiem intensywniejszego podzielania obszaru zainteresowań i modeli teoretycznych, ale też wzorców publikacyjnych. Nie jest też wykluczona rola reputacji czasopism jako czynnika determinującego zakres i schemat ich współafiliowania (por. Zhang $i$ in. 2019). Wprawdzie zakres współdzielonej afiliacji przez te dwie dyscypliny był szerszy, jednak pod względem struktury afiliacji czasopism pedagogika odróżniała się na tle nauk socjologicznych i psychologii, które pozostawały do siebie podobne bardziej niż względem pedagogiki.

Warunki tworzone czasopiśmiennictwu afiliowanemu do pedagogiki nie były gorsze od tych tworzonych czasopiśmiennictwu afiliowanemu do psychologii. Liczba afiliacji do nauk socjologicznych była z kolei co najmniej dwukrotnie wyższa niż do którejś z pozostałych dyscyplin.

$\mathrm{W}$ ramach konkluzji zwracam uwagę, że poza zagadnieniami ujętymi w pytaniach leżących u podstaw zaprezentowanych badań interesujące byłoby także szersze spojrzenie na kontekst dyscyplinarny, w jakim określona została punktacja czasopism afiliowanych do pedagogiki. Mogłoby ono dostarczyć informacji na temat relacji pomiędzy afiliacjami czasopism do pedagogiki oraz pozostałych dyscyplin z obszaru nauk społecznych, nauk humanistycznych i innych. Zwłaszcza że w literaturze podnoszona jest kwestia wzorców punktacji i związanych z nimi wzorców publikowania oraz różnic, podobieństw i relacji pomiędzy środowiskami dyscyplinarnymi w zakresie tychże wzorców (Wijewickrema, Petras 2017). Tym samym dalsze badania nad ostatnią oraz kolejnymi wersjami WCP dostarczyć mogą wiedzy o strukturze powiązań dyscyplinarnych. Wprawdzie, w kontekście ogłoszenia nowego WCP, zaprezentowane wyniki badań mają obecnie wartość głównie porównawczą, to jednak w obliczu braku podobnych przedsięwzięć stanowią punkt odniesienia dla analizy zmian własności punktacji i jej struktury wprowadzanych kolejnymi aktualizacjami WCP.

\section{Bibliografia}

Banaszak S. (2018). Pedagogika ogólna a socjologia ogólna. „Forum Pedagogiczne”, nr 1, s. 135-145.

Casadevall A. i Fang, F. (2012). Reforming Science: Methodological and Cultural Reforms. „Infection and Immunity”, 8o (3), s. 891-896.

Dańda A., Szkup B., Banaszak B., Wewiór P. i in. (2019). Ewaluacja jakości działaności naukowej - przewodnik. Dostępny na: https://konstytucjadlanauki.gov. pl/content/uploads/2019/o3/ewaluacja-jakosci-dzialalnosci-naukowej-przewodnik20190305.pdf (dostęp 15.12.2020)

Ginieis M., Li L. (2020). Sustainability, 12, 1104. 
Kokowski M. (2019). Wprowadzenie do tematyki sesji roboczej „Polskie czasopisma naukowe $z$ dyscyplin: «historia i filozofia nauki» oraz «naukoznawstwo» - aktualne wyzwania" (Kraków, 25 czerwca 2019 r.) i konkretne propozycje rozwiązań organizacyjno-redakcyjnych i legislacyji. „Studia Historiae Scientiarium”, nr 18, s. 494-504.

Kulczycki E. (2017a). Assessing publications through a bibliometric indicator: The case of comprehensive evaluation of scientific units in Poland. „Research Evaluation”, nr 26 (1), s. 41-52.

Kulczycki E. (2017b). Punktoza jako strategia $w$ grze parametrycznej w Polsce. „Nauka i Szkolnictwo Wyższe”, nr 1 (49), s. 63-78.

MNiSW. (2018). Rozporządzenie Ministra Nauki i Szkolnictwa Wyższego z dnia 7 listopada 2018 roku w sprawie sporzadzania wykazów wydawnictw monografi naukowych oraz czasopism naukowych i recenzowanych materiałów $z$ konferencji międzynarodowych. Dostępny na: http://www.bip.nauka.gov. $\mathrm{pl} /$ rozporzadzenia-nauka/rozporzadzenie-ministra-nauki-i-szkolnictwa-wyzszego-z-dnia-7-listopada-2018-r-w-sprawie-sporzadzania-wykazow-wydawnictw-monografii-naukowych-oraz-czasopism-naukowych-i-recenzowanych-materialow-z-konferencji (dostęp 15.12.2020)

Nowak M. (2012). Pedagogiczny profil nauk o wychowaniu. Studium zodniesieniami do pielegniarstwa. Lublin: Wydawnictwo KUL.

Packalen M., Bhattacharya J. (2017). Neophilia Ranking of Scientific Journals. "Scientometrics”, nr 110 (1), s. 43-64.

Palka S. (1999). Pedagogika w stabie tworzenia. Kraków: Wydawnictwo Uniwersytetu Jagiellońskiego.

Śliwerski B. (2007). Cztery orientacje badawcze w teoriach wychowania. W: Pedagogika 2. Podręcznik akademicki. Z. Kwieciński, B. Śliwerski (red.). Warszawa: Wydawnictwo Naukowe PWN.

Śliwerski B. (2020). Pedagogika holistyczna. Studium z perspektywy metanauk społecznych. Warszawa: Wydawnictwo Akademii Pedagogiki Specjalnej.

Wijewickrema M., Petras V. (2017). Journal selection criteria in an open access environment: A comparison between the medicine and social sciences. „Learned Publishing", nr 30, s. 289-300.

Zhang L., Qian Q., Zhang S. i in. (2019). A New Journal Ranking Method: The Reputation Analysis of Citation Behavior Model. „IEEE Access”, nr 7, s. 19382-19, 394. 


\title{
AFFILIATION OF PEDAGOGY, PSYCHOLOGY AND SOCIOLOGICAL SCIENCES JOURNALS IN THE LIGHT OF THE DATA FROM THE LIST OF JOURNALS RANKED BY THE MINISTRY OF SCIENCE AND HIGHER EDUCATION IN 2019
}

\begin{abstract}
One of the basic instruments of science evaluation are journal rankings, which determine the value of publications affiliated with scientific disciplines. The change in evaluation conditions introduced in Poland by the "Constitution for Science" reform sets new conditions not only for the evaluation of journals and published works. This change also allows for the observation of the relationships among scientific disciplines. This article presents the results of a study that used data from the first version of the ministerial list of ranked journals published in 2019. The ranking and co-affiliation of journals for pedagogy and the related disciplines, i.e. psychology and sociological sciences, were analyzed. The results indicate the similarity of the journal rank distributions, and differences in the structure of journal affiliation with the discipline and sharing this affiliation.
\end{abstract}

Keywords: journal scoring, journal affiliation, science reform. 